\title{
Description of the female of Syrittosyrphus opacea Hull, 1944 (Diptera, Syrphidae, Eristalinae) with additional notes on the genus
}

\author{
Axel Ssymank', Kurt Jordaens ${ }^{2}$ \\ I Federal Agency for Nature conservation (BfN, II 2.2), Konstantinstrasse 110, 53179 Bonn, Germany 2 Royal \\ Museum for Central Africa, Invertebrates Section, Leuvensesteenweg 13, B-3080 Tervuren, Belgium \\ Corresponding author: Axel Ssymank (ssymanka@bfn.de) \\ Academic editor: B. Muller | Received 30 November 2020 | Accepted 23 March 2021 | Published 23 April 2021 \\ http://zoobank.org/230C8E00-FB98-4059-B04E-D95090D3B399 \\ Citation: Ssymank A, Jordaens K (2021) Description of the female of Syrittosyrphus opacea Hull, 1944 (Diptera, \\ Syrphidae, Eristalinae) with additional notes on the genus. African Invertebrates 62(1): 339-353. https://doi. \\ org/10.3897/AfrInvertebr.62.61504
}

\begin{abstract}
The taxonomy of Syrphidae is far from being complete in the Afrotropical Region and many species have been described from a single sex only. One of these is the enigmatic monotypic genus Syrittosyrphus Hull, 1944, of which, so far, only the male of Syrittosyrphus opacea Hull, 1944 was described from the Eastern Cape Province in South Africa. Here, we re-describe the male and describe the female. We summarise all known distribution records from South Africa (Eastern Cape, KwaZulu-Natal and Limpopo Provinces) and Zimbabwe (Vumba), of which several are new. We also provide notes on the species' ecology.
\end{abstract}

\section{Keywords}

Afrotropical Region, flower fly, hoverfly, identification

\section{Introduction}

The Afrotropical Region is relatively poor in genera and species of hoverflies or flower flies (Diptera: Syrphidae) (Ssymank et al., in press). Nevertheless, it harbours a number of enigmatic, endemic hoverfly genera. A case in point is the monotypic genus Syrittosyrphus Hull. Syrittosyrphus is a genus within the subfamily Eristalinae and is assumed to be part of the tribe Milesiini although its phylogenetic relationship to other Milesiini remains unknown (see Thompson 1972, 1974; Hippa 1990). Hippa (1990) suggested that the 
closest relatives include Milesia Latreille, Pterallastes Loew and Palumbia Rondani (Hippa 1990), while Hull (1944) suggested that the genus was related to the genus Korinchia Edwards. Phylogenetic analysis of anchored hybrid enrichment molecular data seems to confirm that the sister group of Syrittosyrphus is Korinchia + (Palumbia + Pterallastes) which do not have species in the Afrotropics (Moran et al., unpublished data).

Recently, a complete key to the genera of the Afrotropical Region was compiled (Ssymank et al. in press). Older keys to the Afrotropical genera, such as Curran (1927) and Vockeroth (1969) were incomplete and none included the genus Syrittosyrphus Hull. This genus is monotypic and endemic to southern Africa and its single species Syrittosyrphus opacea Hull, 1944 was described on a single male from Somerset East (Cape Province, South Africa) and deposited at the Natural History Museum UK (NHMUK, formerly the British Museum of Natural History - BMNH). The description of the species is brief and lacks illustrations. Later, Smith and Vockeroth (1980) and Dirickx (1998) list the holotype in their catalogues. Hull (1949) illustrated S. opacea, while Hippa (1990) illustrated the head, metathoracic spiracle, male hind leg and male and female genitalia. Hippa (1990), in his study on the genus Milesia Latreille, studied material from a variety of museums, including the two holdings which, at that time, had S. opacea in their collections, i.e. NHMUK and the KwaZulu-Natal Museum (KZNM, Pietermaritzburg, South Africa; historic acronym: NMSA). It is unclear whether Hippa illustrated the holotype from NHMUK (the only specimen in the collection) or a male from the KZNM. The female illustrated by Hippa (1990) must be one of the females in the collection at KZNM, but apart from the illustration of the female genitalia, morphological details of the female are lacking. Pictures of the male lateral and dorsal habitus and detail of the scutum, taken by X. Mengual (Zoologisches Forschungsmuseum Alexander Koenig, Bonn, Germany) are provided in http://syrphidae.myspecies.info/taxonomy/term/768.

Whittington (1998) studied the D. Cookson collection from Vumba in the Eastern Highlands of Zimbabwe which comprises one male and one female of S. opacea and which are stored at the KZNM. Although the female of S. opacea was obviously known to both Hippa (1990) and Whittington (1998), so far, a description of the female is lacking and the generic diagnosis is based on morphological characters of the male only. Here, we describe, for the first time, the female of $S$. opacea. Since the female differs in some morphological characters from the male, a description of the female is important to properly diagnose the genus and identify the species. This also allowed us to include the genus in the key to the genera of Afrotropical Syrphidae (Ssymank et al., in press).

\section{Material and methods}

Study material was obtained from the following museums and personal collections:

ASPC Axel Ssymank, personal collection, Wachtberg, Germany;

KMMA Koninklijk Museum voor Midden Afrika, Tervuren, Belgium; 
NHMUK Natural History Museum UK, London, UK;

NMSA KwaZulu-Natal Museum, Pietermaritzburg, South Africa;

WBPC Werner Barkemeyer, personal collection, Flensburg, Germany.

Morphological terminology followed Cumming and Wood (2017), except for the segments of the first, second and third pair of legs, for which we have used the prefix pro-, meso- and meta-, respectively. We refer to pollinosity as microtrichia in the form of dust-like pruinescence (Cumming and Wood 2017, p. 89). Body length and wing length were measured using a reticule in a Zeiss SV11 stereomicroscope. Digital images were obtained using the set-up as outlined in Brecko et al. (2014). Stacking was done using the software ZERENE STACKER (www.zerenesystems.com/cms/home). Genitalia were dissected using forceps and soaked for 36 hours in a cold 10\% potassium hydroxide $(\mathrm{KOH})$ solution, after which they were transferred to acetic acid for 24 hours. Afterwards, they were transferred to glycerine. Digital images were taken with a Leica MZ16 microscope using LEICA APPLICATION SUITE (LAS) automontage software (version 3.8). From the specimen voucher AB59880784 (KMMA), we obtained a DNA barcode (GenBank accession number MW698743). Procedures for DNA barcoding followed Jordaens et al. (2015).

\section{Taxonomy and systematics}

\section{Genus Syrittosyrphus Hull}

Syrittosyrphus Hull, 1944: 203. Type species: Syrittosyrphus opacea Hull, 1944, (by monotypy).

Syrittosyrphus opacea Hull-Smith and Vockeroth (1980): 508; Dirickx (1998): 137; Whittington (1998), 39: 193; Whittington (2003), 10: 603.

Differential diagnosis. The genus differs from any other genus of hoverflies in the following combination of characters: scutellum with deep rim and fringe of pile ventrally, metasternum pilose, coxae with long pile, all sternites with long pile, wing cell $r_{1}$ widely open, wing vein $R_{4+5}$ deeply sinuate, stigmal cross-vein present, petiole of anal cell long.

Examined material. Syrittosyrphus opacea Hull: Holotype (Fig. 1), male, "Holo-// type" "Cape Province://Somerset East,//November 1930" "S. Africa.//R.E. Turner.// Brit. Mus.//1930-593." "Holotype//Syrittosyrphus//opacea//Hull" [red label, handwritten] $\left[32.72^{\circ} \mathrm{S}, 25.58^{\circ} \mathrm{E}\right.$; coordinates taken from Gazetteer and therefore approximate] [NHMUK].

Other material. South Africa - 1 Oे; Cathedral Peak Area, KwaZulu-Natal; $28^{\circ} 57^{\prime} S, 29^{\circ} 12^{\prime} E ; 16$ Dec 1977; J.G.H. Londt leg.; NMSA-Dip 53518 (NMSA) • 1 क; Nkandla Forest Reserve, KwaZulu-Natal; 2842'36"S, 318'29"E; 12 Jun 2003; A.J. Armstrong leg.; NMSA-Dip 65136 (NMSA) • 1 क; Royal Natal National Park, 

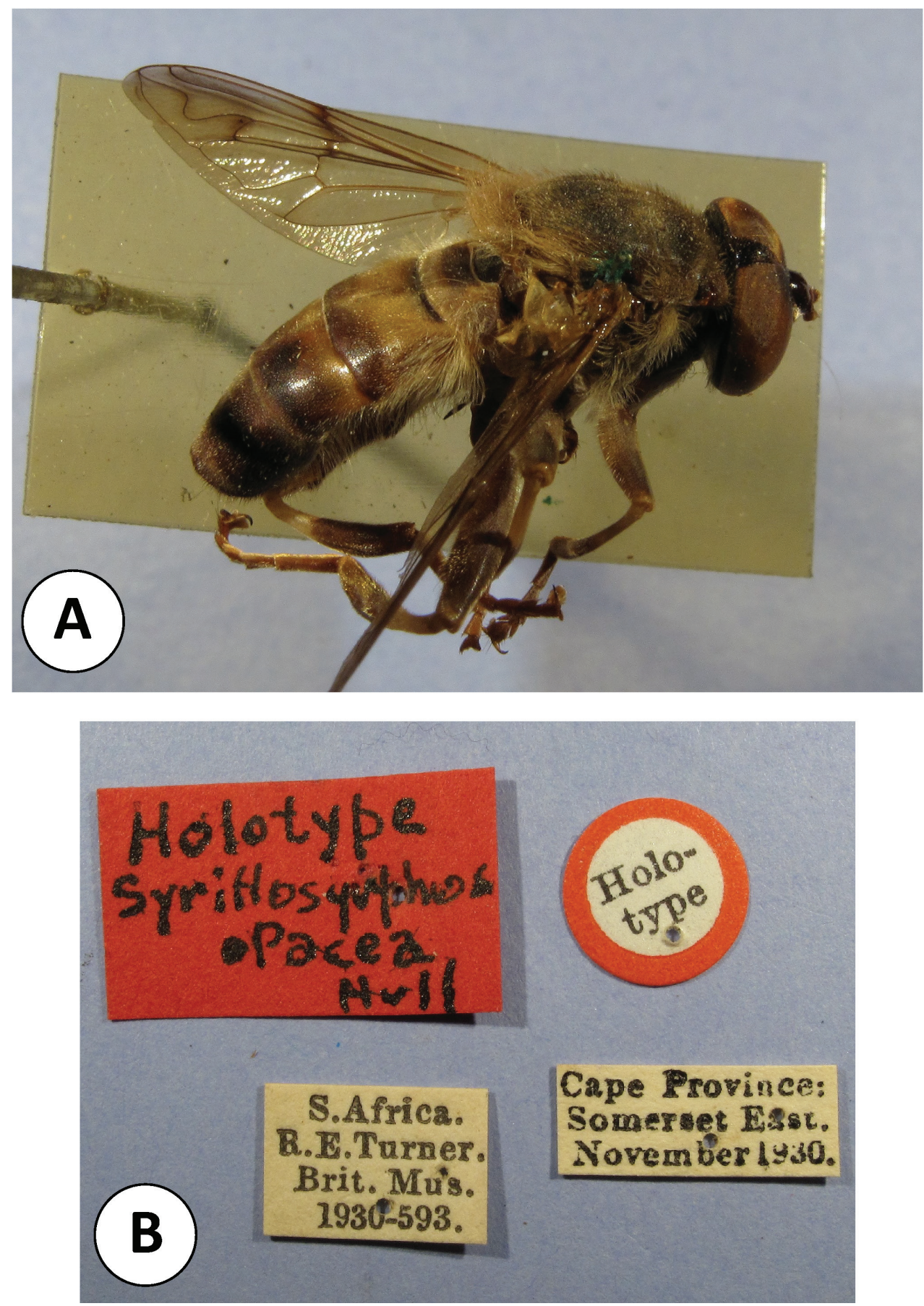

Figure I. Syrittosyrphus opacea Hull, 1944 A dorsolateral view of the male holotype B labels. 
KwaZulu-Natal; 2841'S, 28³9'E; I.1971; H. Townes leg.; NMSA-Dip 51877 (NMSA) - 1 क; Hlatikulu Mountain, Monks Trail Bush edge, KwaZulu-Natal; $28^{\circ} 13^{\prime}$ S, 3001'E; 17 Mar 1997; J.G.H. Londt leg.; NMSA-Dip 015878 (NMSA) • 1 O; Forest Glens, N. Drakensberg, Limpopo Province; $23.96951^{\circ} \mathrm{S}, 29.91860^{\circ} \mathrm{E}$; Dec 2001; J. Swaye leg.; NMSA-Dip 015879 (NMSA)・ 1 q; 10 km E of Bedford, on Adelaide-Bedford Road, roadside Karoo bush, Eastern Cape; 32.6667S, 26.2833E (Gazetteer); [date unknown]; D. Barraclough \& C. Barraclough leg.; NMSA-Dip 049495 (NMSA) - 1 ; ; Royal Natal National Park, Day Visitor Car Park, KwaZulu-Natal; 2841'25.4"S, 2856'53.9"E; 1410 m a.s.l.; 4 Dec 2012; A. Ssymank leg.; (ASPC) • 1 Oे; Karkloof Nature Reserve, KwaZulu-Natal; 29¹7'54.53"S, 30¹8'21"E; 13 Nov 2018, K. Jordaens; KMMA AB59880784; DNA voucher 1179A01 (KMMA) • not studied, but cited in Horn (2004): 1 đ from Forest Glens, northern Drakensberg, Limpopo Province; (WBPC). Zimbabwe 1 O; Vumba; 12 Mar 1964; D. Cookson leg.; NMSA-Dip 32362 (NMSA) • 1 ठ̊; N Vumba; 6 Feb 1966; D. Cookson leg.; NMSA-Dip 32374 (NMSA).

Re-description male. (Figs 2A, 3A, 4A, C, D: all from NMSA-Dip 53518).

Body length: $15.0 \mathrm{~mm}(\mathrm{n}=1)$; wing length: $11.4 \mathrm{~mm}(\mathrm{n}=1)$.

Head [Figs 1 and 4A; see also fig. 6G and H, p.15 in Hippa (1990)]: Eyes holoptic; eye contiguity shorter than length of ocellar triangle. Face yellow with median Yshaped brown non-trichose band, yellow parts densely pale pollinose; pale setose. Gena ochre with brownish-black band from oral margin to eye margin. Clypeus subquadrate, broad, dark brown, greyish microtrichose. Lunule brownish-orange. Frons above antennae dark brown shining, non-pollinose, inflated, with a small central round depression. Frontal triangle brownish to black setose on anterior inferior part, with pale setae dorsally, non-pollinose, except narrowly along eye margin. Ocellar triangle equilateral, ocelli reddish, bare. Occiput pale greyish microtrichose; pale setose. Antennae with scapes and pedicel brownish, non-pollinose; postpedicel twice as long as wide, yellowish, densely greyish pollinose; arista yellow, bare, about 2-2.5 times as long as postpedicel.

Thorax (Figs 1, 2A and 3A): Dark brown to black, scutum yellow pollinose along margins and suture and in anterior part, also along median line, leaving large brownish-black non-pollinose areas with blackish setae. Scutellum yellow, width to length ratio 2.5:1, with premarginal sulcus, long yellow densely setose (setae ca. 1/3-1/2 length of scutellum); subscutellar fringe well developed with dense long yellow setae of ca. $0.45 \mathrm{~mm}$. Pleurae brownish, mostly densely grey pollinose; postpronotum with a small pronounced non-pollinose bulge leading into an elevated rim of the scutum, with yellow and a few black setae intermixed; anterior anepisternum, posterior part of proepimeron and anterior part or posterior anepisternum bare; proepisternum, posterior part of anepisternum and anterior anepimeron with long yellow setae; katepisternum with posteriodorsal tuft of long setae and ventrally setose; meron, metepimeron, katepimeron, katatergite, posterior anepimeron, except for some short microsetae, bare; metasternum densely long yellow setose. Ampulla yellow. Plumula yellowish. Thoracic spiracles with whitish to ochre vestiture. 

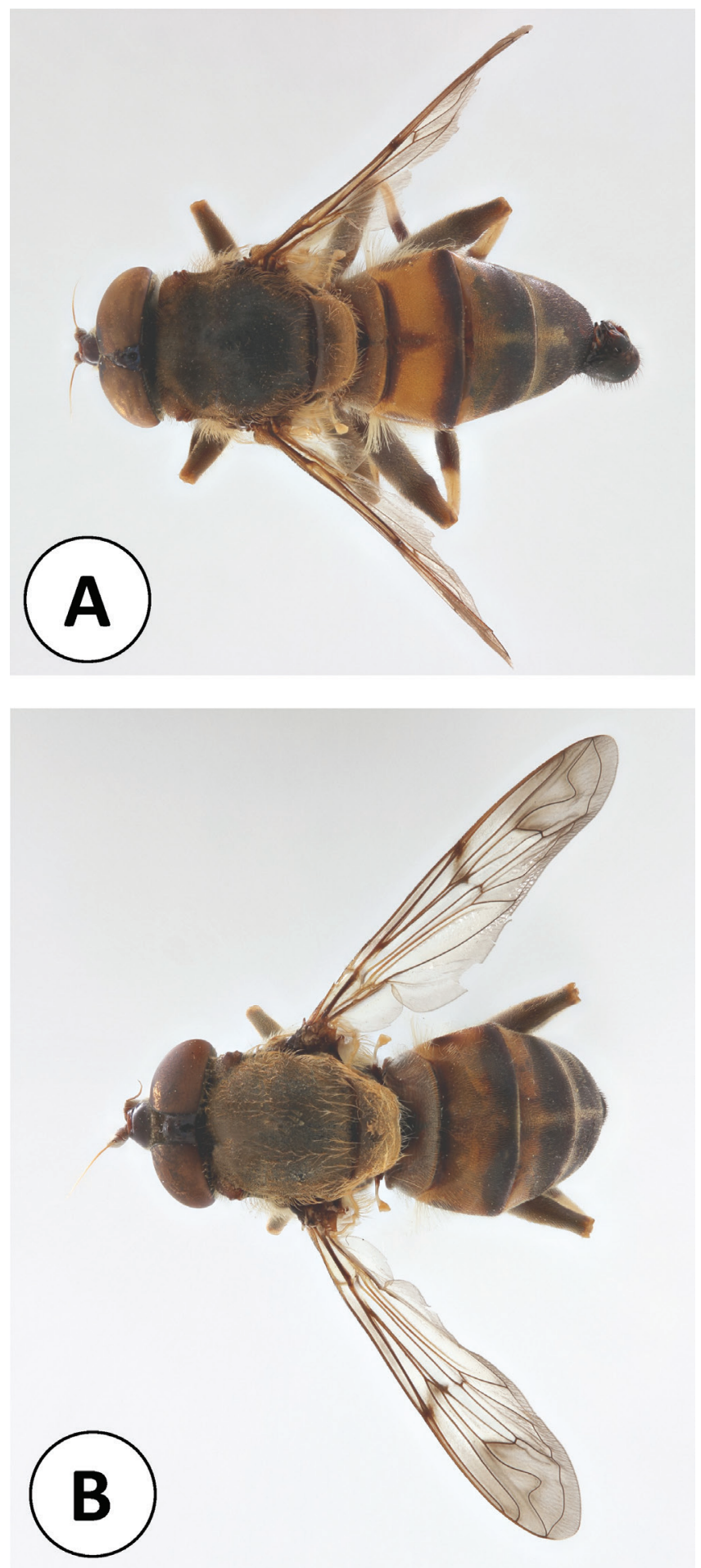

Figure 2. Syrittosyrphus opacea Hull, 1944 A dorsal view male B dorsal view female. 

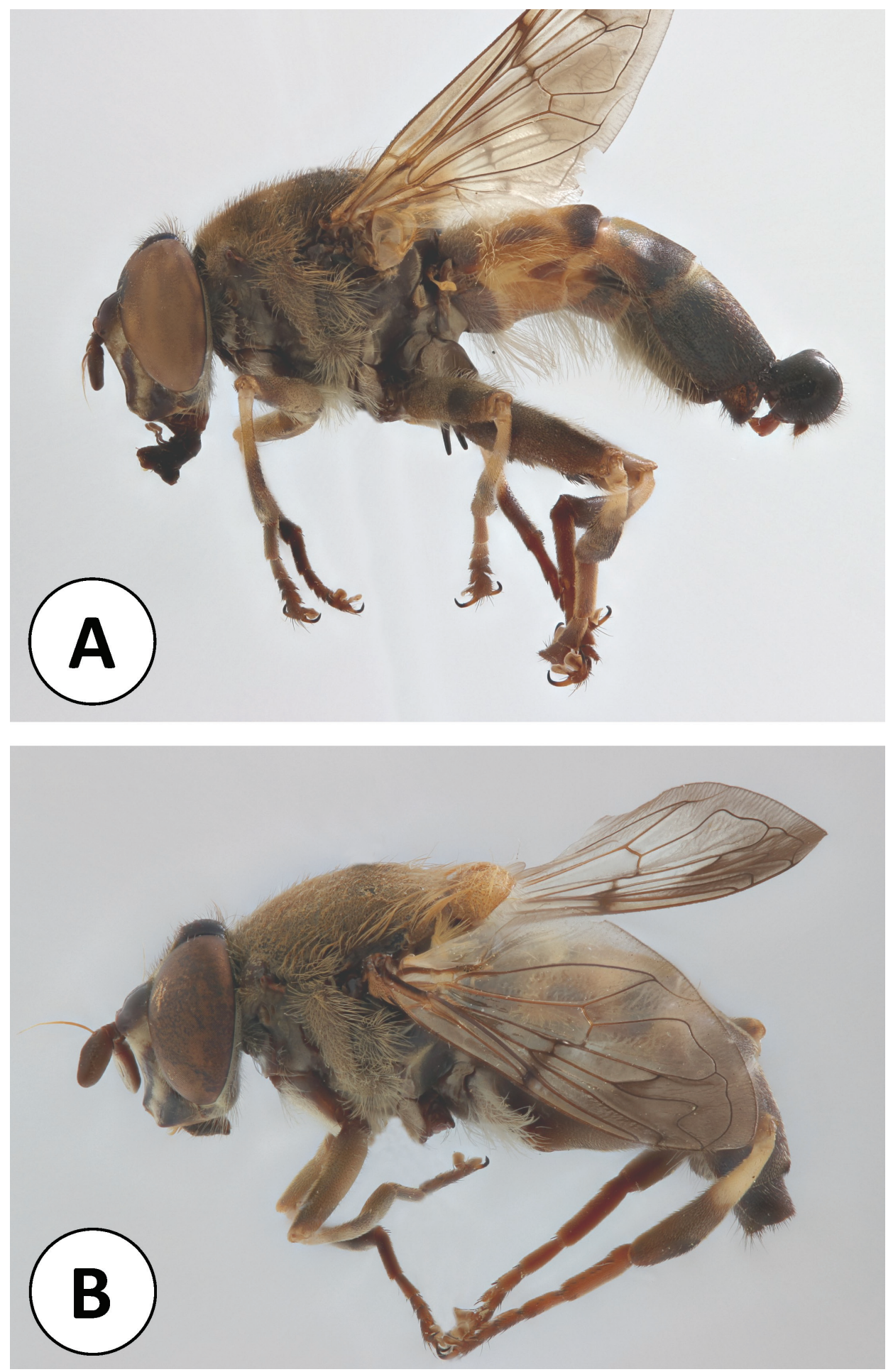

Figure 3. Syrittosyrphus opacea Hull, 1944 A lateral view male B lateral view female. 
Legs [Figs 1, 2A, 3A and 4C: see also fig. 6E and F, p. 16 in Hippa (1990)]: reddishbrown, tibia with basal $1 / 3$ to $1 / 2$ yellow. Mesofemur posteriorly grey pollinose, anteriorly with a broad median pollinose band; short adpressed yellowish setae; tarsae ventrally with short stout black setulae. Mesotibia abruptly broadened in apical 1/4. Mesofemur posterolateral with a row of longer whitish setae (length ca. 1/2 diameter of mesofemur). Mesotibia slightly dilated apically with apicoventrally a short comb of short black stout setulae and a small pointed tooth on the opposite side. Metacoxa (Fig. 4C) with two black spurs of ca. 1 $\mathrm{mm}$ long. Metafemur with posterolateral row of longer whitish setae (length ca. 1/3 of diameter of metafemur); ventrobasally with a low ridge carrying a black comb of short stout black setulae; apicoventrally with a depression that carries a ridge with a row of black stout setae on the anterior side. Metatibia yellow, apical 2/3 brownish; dilated towards apex, apical half carinate posteriorly; anteriorly with an oblique depression at $1 / 4$ from apex.

Wing (Figs 1, 4D): hyaline, along anterior margin yellowish with darkened patches below pterostigma extending to cross-vein $r-m$, wing tip slightly darkened. Anal cell very long. Cell $r_{1}$ widely open, in apical half widened and close to wing margin suddenly narrowed, ending at wing margin. Vein $R_{4+5}$ with a deep oblique sinuate loop into cell $r_{4+5}$. Spurious vein well developed, as thick as other veins, extending into cell $r_{4+5^{\circ}}$ Anal cell microtrichose with basal area bare. Basal half of wing up to cross-vein $r-m$ with sparse microtrichia, with bare areas along veins; apical $1 / 3$ of wing (including entire cell $\left.r_{4+5}\right)$ densely microtrichose. Calypters white with an orange-brown margin, long yellow-white pilose. Halteres yellow-brown.

Abdomen (Figs 1, 2A, 3A): long and conical; setae from tergites I to IV mostly yellowish short and adpressed, only on lateral margins longer yellow setae. Tergite I yellow to ochre, densely greyish pollinose with the exception of a narrow non-pollinose posterior margin. Tergite II with large orange maculae, with lateral, anterior and posterior margins brownish to black; slightly darkened along median line; mostly nonpollinose. Tergite III narrowly yellow along anterior margin, otherwise dark brown; with sparse, but distinct yellowish to grey pollinosity, pollinosity more dense along median line and towards posterior margin. Tergite IV brownish-black, only anterior part of median line greyish pollinose. On tergites II-IV, the dark coloured parts have short blackish setulae. Hypopygium with brownish-black long setae. Sternite I brownish, densely grey pollinose. Sternite II yellow with black median line; only along anterior margin whitish pollinose. Sternite III anterior and posterior margin yellow, with central broad brownish-black fascia, uniform, but weak pollinose. Sternites I-III with very long dense setae of ca. $2 \mathrm{~mm}$ length. Sternite IV brownish-black, distinctly greyish pollinose laterally, with long setae that form a dense comb along lateral margin, leaving a median non-pollinose, almost bare, area of approx. $1 / 4$ to $1 / 3$ of sternal width.

Genitalia [Fig. 5A, B; see also fig. 6A and B, p. 15 in Hippa (1990)]: Epandrium with surstylus dorsally from halfway strongly curved downwards, pointed, ventrally with subtriangular expansion, dorsally and ventrally long yellow-brown pilose. Hypandrium very large and ventrally broadly expanded; aedeagus with a ventral sharp tooth. Cerci broad, club-shaped; on posterior and ventral side long yellow-brown pilose. 

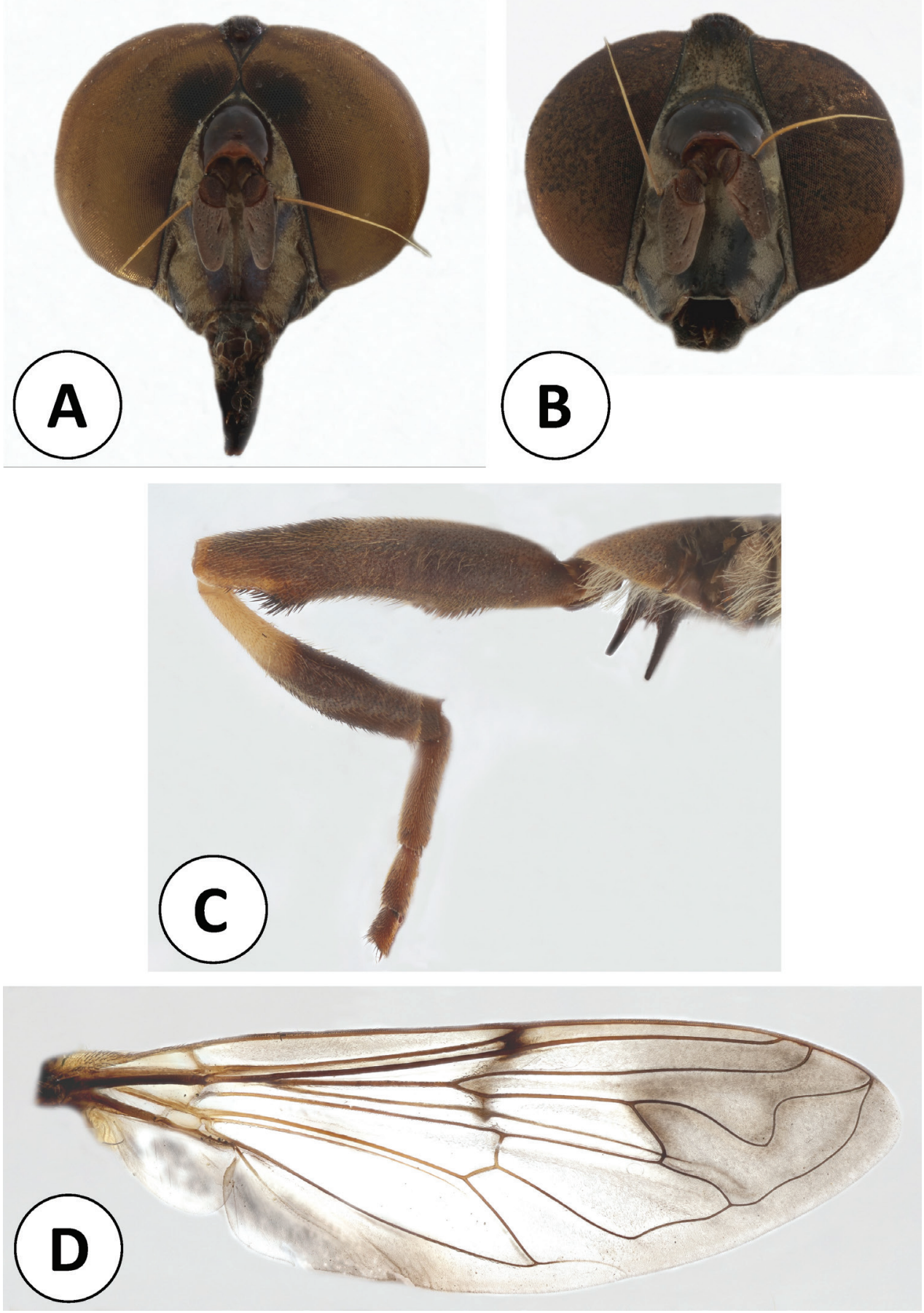

Figure 4. Syrittosyrphus opacea Hull, 1944 A head male, frontal view B head female, frontal view $\mathbf{C}$ metaleg male, posterior view $\mathbf{D}$ right wing male. 


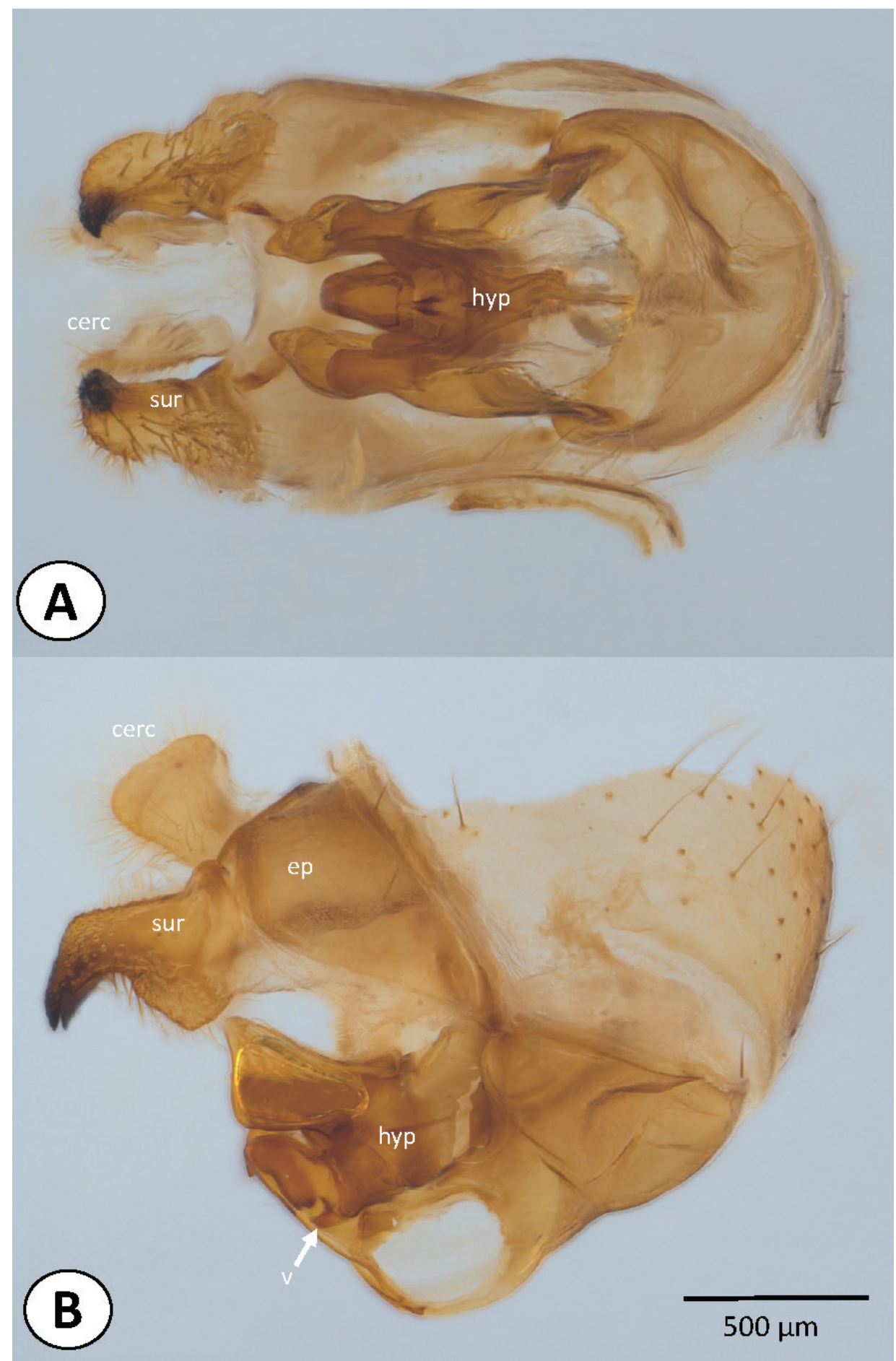

Figure 5. Male genitalia of Syrittosyrphus opacea Hull, 1944 A ventral view B lateral view. Abbreviations: cerc, cercus; ep, epandrium; hyp, hypandrium; v, ventral tooth of the aedeagus. 
Description female. Figs 2B, 3B, 4B (specimen NMSA-Dip 65136) and 6 (ASPC).

Body length: $14.0 \mathrm{~mm}(\mathrm{n}=1)$; wing length: $11.4 \mathrm{~mm}(\mathrm{n}=1)$

Similar to male, except for distinct sexual dimorphism. Frons with a broad greyish pollinose band with grey setae (Fig. 4B). Ocellar triangle and upper part of frons brownish-black, non-pollinose, brownish to black setose (Fig. 2B). Legs (Figs $2 \mathrm{~B}$ and 3B): protibia less broadened in apical third. Mesoleg without black setal comb on tip of tibia. Metaleg: coxa without long spur; femur with very low ventral bump, with some stout black setae; basoventral patch of black setae missing; no long pale setae posterolaterally. Abdomen (Figs 2B, 3B): Tergite $\mathrm{V}$ black, non-pollinose, black setose, but shorter than in male. Sternites with long pale setae much shorter and less dense than in male $(1.5 \mathrm{~mm}$ on sternite II, $0.65 \mathrm{~mm}$ on sternite V); sternite III + IV with scattered longer setae only; sternite $\mathrm{V}$ with only a few longer setae. Genitalia (Fig. 6) compact, tergite 7 approx. $1.5 \times$ as broad as long, tergite 8 approx. as long as broad, posteriorly rounded, without lateral apodemes, with very long evenly distributed long yellow-brown pile; epiproct broad, with two rounded anterior areas and with a single basal area with two triangular large apodemes, with a granulated small lateral lobe to the epiproct; sternite 8 large, with an unusual ventral modification, ventrally concave; sternite 9 with conspicuous pigmentation at apical margin; cerci rounded, semi-circular, apical end gently curved inwards, long yellow-brown pilose.

Distribution. South Africa (Hull 1944; this study), Zimbabwe (Whittington 1998) (Fig. 7).

\section{Discussion}

We here have described, for the first time, the female of the Afrotropical hoverfly, Syrittosyrphus opacea, which allowed us to update the diagnosis of this monotypic genus. As a result, the genus now correctly keys out in a key to the genera of Syrphidae of the Afrotropical Region (Ssymank et al., in press). We obtained a single DNA barcode and the uncorrected p-distance with any other Afrotropical hoverfly species is $\geq 10 \%$. Its closest relative in the Afrotropical Region seems to be an undescribed species from the Ruwenzori Mountains in Uganda which we currently cannot attribute to any known genus (Jordaens et al., unpublished data).

Syrittosyrphus opacea seems to be a SE African endemic and, so far, has only been recorded from South Africa (nine localities) and Zimbabwe (one locality) (Fig. 7). The species is very rare with, up to now, five males and seven females known (see list of Material Studied). Very little is known of its ecology, but all specimens were collected from November to mid-March, except for one which was collected in June. Judging from the indigenous forest map of South-Africa (fig. 12.2, p. 586 or fig. 12.3, p. 588 in Mucina and Geldenhuys 2006), the species seems to occur in Southern Mistbelt Forests (Somerset East (type locality), Bedford, Karkloof Nature Reserve, Nkandla Forest Reserve), Northern Mistbelt Forests (Forest Glens) or Northern Afrotemperate Forests (Cathedral Peak Area, Royal Natal National Park, Hlatikulu Mountain). The localities 


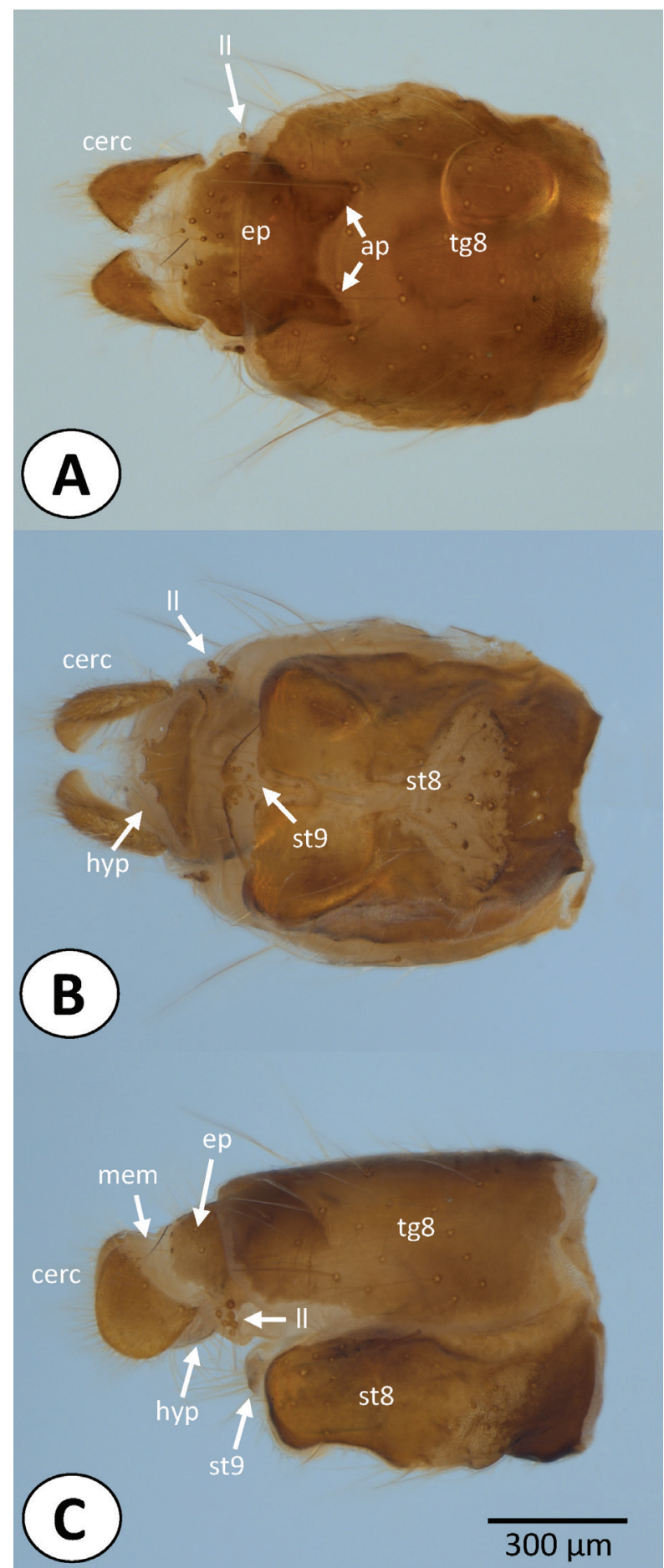

Figure 6. Female genitalia of Syrittosyrphus opacea Hull, 1944 A dorsal view B ventral view C lateral view. Abbreviations: ap, apodeme of epiproct; cerc, cercus; ep, epiproct; hyp, hypoproct; 11, lateral lobe to the epiproct; mem, membranous area between epiproct and cerci; st8, sternite 8 ; st9, sternite 9; tg8, tergite 8 . 


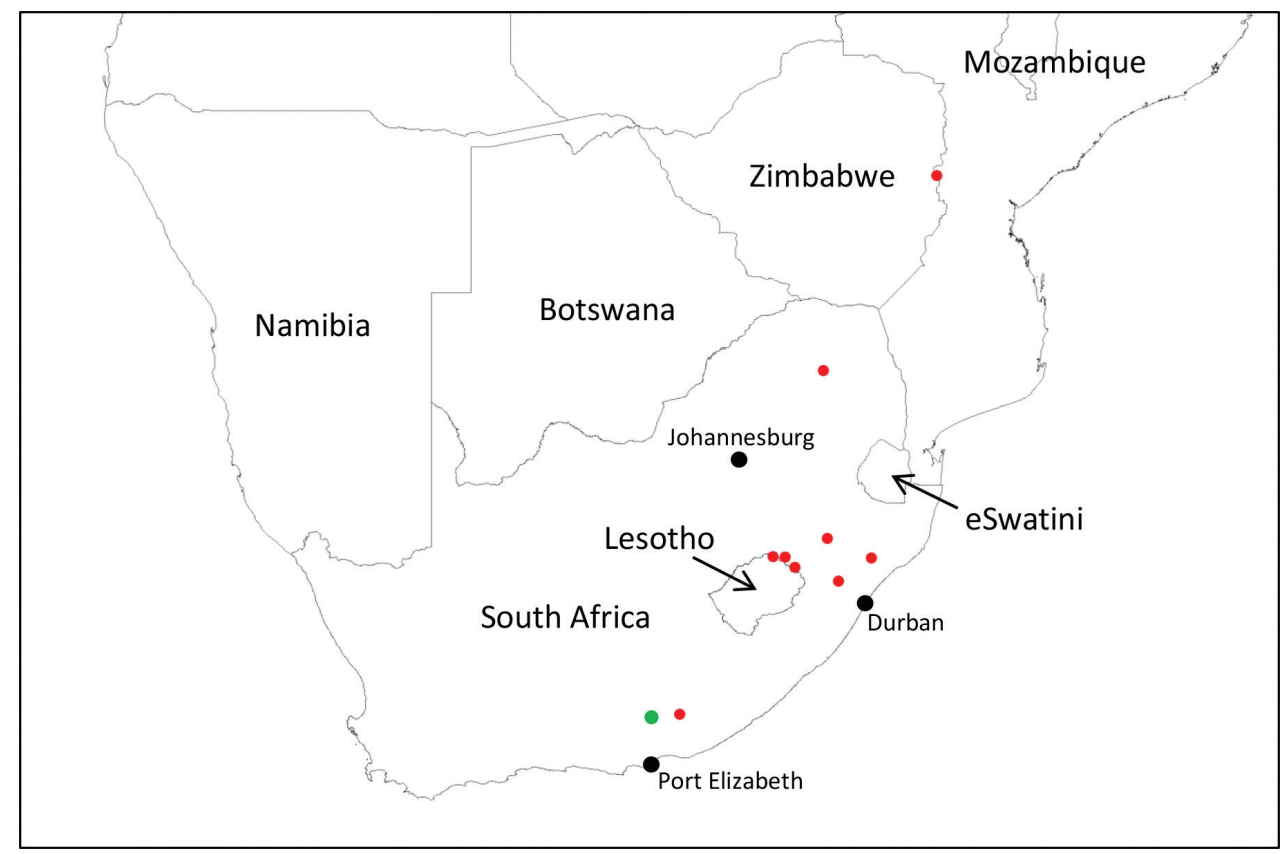

Figure 7. Distribution of Syrittosyrphus opacea Hull, 1944 in South Africa and Zimbabwe. Red dots: distribution records; green dot: type locality.

at Cathedral Peak Area and Royal Natal National Park are not indicated on the map in Mucina and Geldenhuys (2006), but these areas still have small forest patches (J. Midgley, pers. comm.; as in fig. 12.5, p. 590 in Mucina and Geldenhuys 2006). Additionally, the Vumba mountains (Zimbabwe) would classify as Northern Afrotemperate Forest. Flower visits have not been observed, but the short stout proboscis $(2.6-3.1 \mathrm{~mm})$ with broad labellum suggests that the species is visiting open flowers. Adults have been observed sitting on the ground at forest margins or in sun-lit patches on the forest floor. Some have been collected from Malaise traps. Immature stages are unknown.

With the detailed re-description of the male and the description of the female provided here, both sexes of Syrittosyrphus opacea can now be unambiguously identified. The available records of this rare SE African endemic species suggest a distribution linked to three forest types along the Eastern Escarpment (Northern Afrotemperate Forest and Northern and Southern Mistbelt Forests). Based on these habitats, together with vegetation maps, future research may close distribution gaps and clarify the biology.

\section{Acknowledgements}

We would like to thank Kirstin Williams and John Midgley (KwaZulu-Natal Museum, Pietermaritzburg, South Africa) and Burgert Muller (now at the National Museum, Bloemfontein, South Africa) for sending us specimens on loan and for information on the distribution records and habitats. We thank Menno Reemer, Gil Felipe 
Gonçalves Miranda and an anonymous referee for their valuable comments which have improved the manuscript considerably. We also thank Gil Felipe Gonçalves Miranda for a fruitful discussion on the female genital morphology. Financial support was received through the Directorate-general Development Cooperation and Humanitarian Aid (DGD) to the RMCA (project DIPoDIP: Diversity of Pollinating Diptera in South African Biodiversity Hotspots) and the joint Belspo-NRF South Africa project DIPTATEACH (Diptera Museum Collections as a Source for Taxonomic Research and Teaching Activities).

\section{References}

Brecko J, Mathys A, Dekoninck W, Leponce M, VandenSpiegel D, Semal P (2014) Focus stacking: Comparing commercial top-end set-ups with a semi-automatic low budget approach. A possible solution for mass digitization of type specimens. ZooKeys 464: 1-23. https://doi.org/10.3897/zookeys.464.8615

Cumming J, Wood M (2017) 3. Adult morphology and terminology. In: Kirk-Spriggs AH, Sinclair BJ (Eds) Manual of Afrotropical Diptera, Volume 1. Introductory chapters and keys to Diptera families. Suricata 4, South African National Biodiversity Institute, Pretoria.

Curran CH (1927) II. Diptera of the American Museum Congo Expedition. Part I. Bibionidae, Bornbyliidae, Dolichopodidae, Syrphidae and Trypaneidae. Bulletin of the American Museum of Natural History 57: 33-89. http://digitallibrary.amnh.org/ handle/2246/1640?show=full

Dirickx HG (1998) Catalogue Synonymique et Géographique des Syrphidae (Diptera) de la Région Afrotropicale. Muséum d'Histoire Naturelle Genève, Genève, [x +] 187 pp.

Hippa H (1990) The genus Milesia Latreille (Diptera: Syrphidae). Acta Zoologica Fennica, 187: $1-226$.

Horn JL (2004) The invertebrates of indigenous forests in Limpopo Province, South Africa: Diversity, biogeography and conservation. MSc thesis, Pietermaritzburg, South Africa: M.Sc School of Botany and Zoology, Faculty of Science and Agriculture, University of KwaZulu-Natal, 267 pp.

Hull FM (1944) Some syrphid fly genera (Diptera). Entomological News 55: 203-205. https:// www.biodiversitylibrary.org/part/16502\#/summary

Hull FM (1949) The morphology and inter-relationships of the genera of syrphid flies, recent and fossil. Transactions of the Zoological Society of London XXVI: 257-408. https://doi. org/10.1111/j.1096-3642.1949.tb00224.x

Jordaens K, Goergen G, Virgilio M, Backeljau T, Vokaer A, De Meyer M (2015) DNA barcoding to improve the taxonomy of the Afrotropical hoverflies (Insecta: Diptera: Syrphidae). PLoS ONE 10(10): 1-15. https://doi.org/10.1371/journal.pone.0140264

Mucina L, Geldenhuys CJ (2006) 12. Afrotemperate, subtropical and Azonal forests. In: Mucina L, Rutherford MC (Eds) The vegetation of South Africa, Lesotho and Swaziland. Strelitzia 19, South African National Biodiversity Institute, Pretoria. 
Smith KGV, Vockeroth D (1980) 38. Family Syrphidae. In: Crosskey D, Cogan BH, Freeman P, Pont A, Smith KGV, British Museum (Natural History) (Eds) Catalogue of the Diptera of the Afrotropical Region. British Museum (Natural History), London.

Ssymank A, Jordaens K, De Meyer M, Reemer M, Rotheray GE (in press) 60. Syrphidae (Flower Flies or Hoverflies). In: Kirk-Spriggs AH, Sinclair BJ (Eds) Manual of Afrotropical Diptera, Volume 3. Brachycera-Cyclorrhapha, excluding Calyptratae. Suricata, South African National Biodiversity Institute, Pretoria.

Thompson FC (1972) A contribution to a generic revision of the neotropical Milesinae (Diptera: Syrphidae). Arquivos de Zoologia 23: 73-215.

Thompson FC (1974) The genus Pterallastes Loew (Diptera: Syrphidae). Journal of the New York Entomological Society 82: 15-29.

Vockeroth JR (1969) A revision of the genera of the Syrphini (Diptera: Syrphidae). Memoirs of the Entomological Society of Canada 62: 1-176. https://doi.org/10.4039/entm10162fv

Whittington AE (1998) Hoverflies (Diptera: Syrphidae) from Vumba, Eastern Highlands of Zimbabwe, with the description of a new species of Paragus. Annals of the Natal Museum 39: 185-198. https://journals.co.za/content/annals/39/1/AJA03040798_149

Whittington AE (2003) The Afrotropical Syrphidae fauna: An assessment. Studia Dipterologica 20: 579-607. 